Tropical Journal of Pharmaceutical Research April 2018; 17 (4): 605-609

ISSN: $1596-5996$ (print); 1596-9827 (electronic)

(C) Pharmacotherapy Group, Faculty of Pharmacy, University of Benin, Benin City, 300001 Nigeria.

\title{
Investigation of the potential role of checkpoint kinase2 in the regulation of gastric cancer stem cells
}

\author{
Lin-Hua Ji, Bin Zhang, Gang Zhao* \\ Department of Gastrointestinal Surgery, Ren Ji Hospital, School of medicine, Shanghai Jiao Tong University, Shanghai, China
}

${ }^{*}$ For correspondence: Email: 13564383793@163.com; Tel/Fax: 86-021-68383732

Sent for review: 31 November 2017

Revised accepted: 29 March 2018

\begin{abstract}
Purpose: To investigate the potential role of checkpoint kinase2 (CHEK2) in regulating gastric cancer stem cells.

Methods: The abnormal features of cellular arrangements in early and advanced stages of gastric cancer were analysed using histology. Immunohistochemistry and Western blotting were used to evaluate the expressions of cancer stem cell markers CD44 and CHEK2 at different stages of gastric cancer.

Results: When compared with the control tissue, the size of the cellular nucleus was enlarged as the gastric tumour developed to more advanced stages, and the expression of CD44 increased exponentially. The expression of CHEK2, a protein that regulates cell cycle and apoptosis was aberrantly up-regulated at the early stage of cancer, but as the tumour advanced, its expression became down-regulated.

Conclusion: These results show that the higher expression of CHEK2 at the early stages of gastric cancer exerts control over gastric cancer stem cell proliferation. Thus, CHECK2 is a potential target for early treatment of gastric cancer.
\end{abstract}

Keywords: Gastric cancer, CD44, CHEK2, Gastric cancer stem cells

\begin{abstract}
This is an Open Access article that uses a funding model which does not charge readers or their institutions for access and distributed under the terms of the Creative Commons Attribution License (http://creativecommons.org/licenses/by/4.0) and the Budapest Open Access Initiative (http://www.budapestopenaccessinitiative.org/read), which permit unrestricted use, distribution, and reproduction in any medium, provided the original work is properly credited.

Tropical Journal of Pharmaceutical Research is indexed by Science Citation Index (SciSearch), Scopus, International Pharmaceutical Abstract, Chemical Abstracts, Embase, Index Copernicus, EBSCO, African Index Medicus, JournalSeek, Journal Citation Reports/Science Edition, Directory of Open Access Journals (DOAJ), African Journal Online, Bioline International, Open-J-Gate and Pharmacy Abstracts
\end{abstract}

\section{INTRODUCTION}

Gastric cancer is a tumour that develops inside the lining of the stomach, and it constitutes a major health problem worldwide $[1,2]$. When it is not treated at the early stage, it can spread to other organs in the body like liver, abdomen, lungs, bones and lymph nodes [3]. Due to the nature of its occurrence and metastasis capacity, gastric cancer ranks third as the most leading cause of cancer mortality [4]. The aetiology of gastric cancer is associated with many environmental factors such as dietary patterns, Helicobacter pylori infection and host response $[5,6]$. Although the 5-year survival of gastric cancer has continued to improve, it is still poor, considering that the median survival is less than one year for patients diagnosed with metastasized gastric cancer [7-9].

Cancer stem cells are small population of cells that possess stem cell-like properties which are responsible for the resistance to treatment, as well as the aggressive nature of cancer [10-12]. 
To control the incidence of gastric cancer, and to provide effective treatment, there is an urgent need to identify effective biomarkers with therapeutic value that are linked with cancer stem cells $[13,14]$. Checkpoint kinase2 (CHEK2) gene monitors checkpoints of the cell cycle that regulate cell division. Mutation in CHEK2 gene results in the development of cancer types like colorectal [15], breast [16], and prostate [17]. When subjected to genomic stress, p53 and CHEK2 are activated by ataxia telangiectasia mutated (ATM) protein, and thereby involved in DNA repair, regulate cell cycle and senescence $[18,19]$. It is important to investigate the expression of CHEK2 at different stages of tumour progression along with markers of cancer stem cells, so as to reveal their link with cancer stem cell, specifically with cancer progression. The present study was carried out to investigate the level of expression of CHEK2 and markers of gastric cancer stem cell so as to identify their association with cancer progression.

\section{EXPERIMENTAL}

\section{Clinical samples from patients}

Tissues from early stage and metastasis form of gastric cancer were obtained from 126 patients (68 males and 58 females) who underwent treatment at the Department of Gastrointestinal Surgery, Ren Ji Hospital, School of Medicine, from June 2012 to October 2015. The median age of the patients was 54 years (ages ranged from 43 to 68). The patients were examined, and gastric cancer tissue samples were removed for further analysis. The patients are subjected to open surgery, or to laparoscopy-assisted gastrectomy in line with international guidelines recommended by Japanese Gastric Cancer Association [20]. On the whole, 32 samples were with normal gastric mucosa, 66 samples had early stage of cancer, while 28 samples had advanced stage of gastric cancer. The study was approved by the Institutional Review Board of Shanghai Jiao Tong University (no. TYY2135).

\section{Histological analysis}

The samples were washed with distilled water and fixed with $10 \%$ formalin solution. After $48 \mathrm{~h}$ of fixation, the gastric tissue samples were once again washed with water and subjected to dehydration process. The samples were transferred to increasing concentrations of ethanol (60, 70, 80, 90 and $100 \%)$ for complete removal of water, and the dehydrated tissue samples were cleared in xylene for $45 \mathrm{~min}$. The tissues were then impregnated with liquid wax, and traces of xylene were completely removed by transferring to fresh liquid wax. The tissues were finally embedded in paraffin after overnight incubation. They were subsequently sectioned with microtome to $6 \mu \mathrm{m}$ slices which were stained with hematoxylin and eosin (H \& E).

\section{Immunohistochemistry}

The dissected sections were de-waxed, and their endogenous peroxide activity was specifically blocked by incubating in $10 \% \mathrm{H}_{2} \mathrm{O}_{2}$. After blocking the non-specific sites with $5 \% \mathrm{BSA}$ solution, the tissues were incubated with primary antibody anti-CD44 (Abcam, ab51037) or antiCHEK2 (Abcam, ab109413) overnight at $4 \stackrel{\circ}{\circ}$. After washing the sections with 1X PBS, the tissues are overlaid with appropriate secondary antibody for $2 \mathrm{~h}$ at room temperature. The sections were washed twice with $1 \mathrm{X}$ PBS, and signals were determined using $D A B$ reagent.

\section{Western blotting}

Pre-chilled tissues were homogenized in $2 \mathrm{X}$ protein sample buffers and heated in boiling water bath for $5 \mathrm{~min}$ to separate the protein samples. Protein estimation was done using Lowry method [21], and each lane of the gel was loaded with $80 \mu \mathrm{g}$ of protein samples to resolve them in $12 \%$ SDS PAGE gel. When the dye reached the bottom of the protein, the gel was transferred to PVDF membrane. The membrane was then incubated in $5 \%$ skimmed milk powder in TBST for $2 \mathrm{~h}$ at room temperature, and thereafter incubated with primary antibody antiCD44 (Abcam, ab51037) or anti-CHEK2 (Abcam, ab109413) overnight at 4 으. Non-specific binding of antibody was washed out thrice with TBST solution, and the membrane was further incubated with HRP-conjugated suitable secondary antibody for $1 \mathrm{~h}$ at room temperature. After final washing with TBST solution, the membrane was developed with DAB kit.

\section{Statistical analysis}

The assays carried out were carried out in triplicate and the results presented as mean \pm SD. The data were statistically analysed using student t-test and one-way analysis of variance (ANOVA). Values of $p$ less than 0.05 were considered as significant.

\section{RESULTS}

\section{Changes in gastric tissue morphology}

The histology of gastric tissue from the control group showed distinct cells with nuclei evenly distributed throughout the tissue layer, with 
mucosa layer nuclei being small in size (Figure 1 A). On the other hand, the histological section of early stage gastric cancer tissue showed enlarged nuclei with some of the cells clumped together, and the cells had irregular structures (Figure $1 \mathrm{~B}$ ). Initiation of signet ring cell was also observed, which is a characteristic feature of gastric cancer (Figure $1 \mathrm{~B}$ ). Gastric tissue from advanced stage gastric cancer showed larger nuclei than in early stage gastric cancer, with pronounced distortion of the regular tissue pattern (Figure $1 \mathrm{C}$ ). Irregular polygonal tumour cells with aggressive cellular proliferation were also seen (Figure $1 \mathrm{C}$ ).

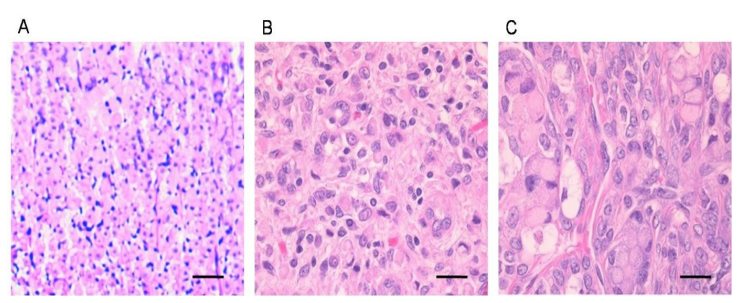

Figure 1: Morphology of early and advanced stage gastric cancer tissues, (A): Control gastric tissue subjected to histological analysis showing cells with minimal and normal size nuclei, (B): Early stage gastric cancer showing enlarged nuclei and initiation of signet ring cells, (C): Advanced stage gastric cancer with irregular polygonal tumour cells and highly proliferative cells

\section{Correlation between CD44 and CHEK2 expressions}

CD44 is an adhesion molecule that exists on the cell surface of gastric cancer stem cells, and it plays a role in tissue invasion [22]. Using immunohistochemistry, the expression profiles of CD44 and CHEK2 were analysed to understand their link with each other. In the control tissue, the expression of CD44 was highly restricted with low or minimum signals (Figure 2 A). However, CD44 expression was up-regulated in early gastric cancer (Figure $2 \mathrm{~B}$ ), and showed multifold increase as the tumour developed to an advanced stage (Figure $2 \mathrm{C}$ ). Similarly, the expression of CHEK2 showed minimal signals in control tissue (Figure 2D), but an increased pattern of expression was evident in early stage gastric cancer (Figure $2 \mathrm{E}$ ). As the tumour developed to the advanced stage, statistically significant down-regulation of CHEK2 signals was observed (Figure $2 \mathrm{~F}$ ).

\section{Expression of CD44 and CHEK2}

Immuno-histochemical data were further analysed using western blotting. The expression profiles of CD44 and CHEK2 were minimal in the control tissue (Figure 3, Lane 1), but in the early stage gastric cancer, their expressions became up-regulated (Figure 3, Lane 2). The expression of CD44 showed an up-regulated pattern as the tumour progressed to the advanced stage, but CHEK2 expression was down-regulated (Figure 3, Lane 3).
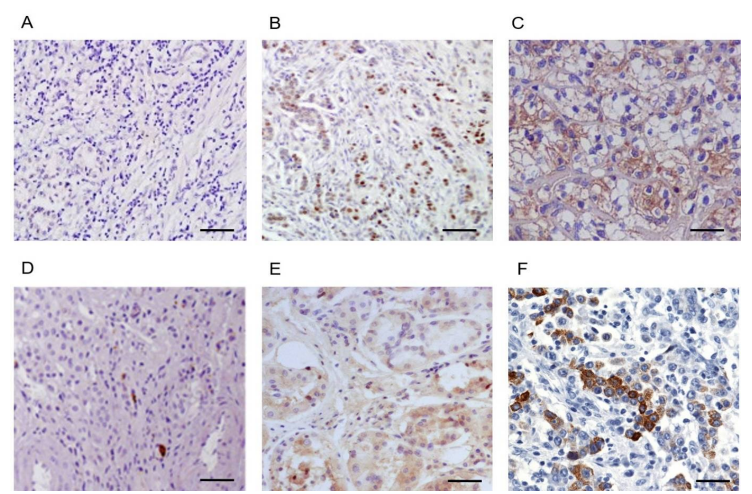

$\mathrm{E}$
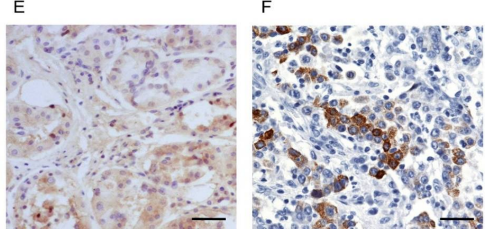

Figure 2: Immuno-histochemical analysis of the correlation between CD44 and CHEK2 expression. (A): Weak expression of CD44 in control gastric tissue, (B): Moderate expression of CD44 in early stage gastric cancer, (C): Advanced stage gastric cancer with significant over-expression, (D): Control gastric tissue showing faint expression of CHEK2, (E): Upregulated expression of CHEK2 in early stage gastric cancer, $(F)$ : Prominent down-regulation of expression of CHEK2 in advanced stage gastric cancer

L1

L2 L3
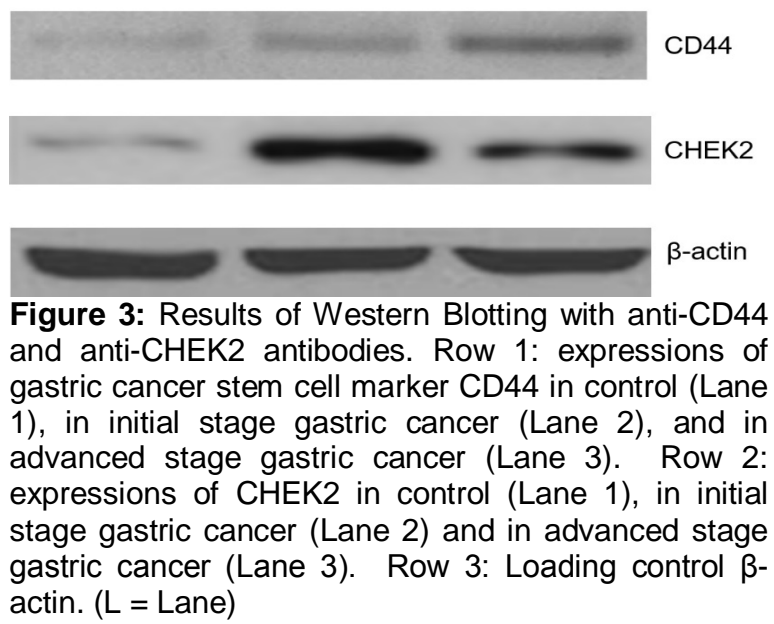

\section{DISCUSSION}

Research in the area of gastric cancer stem cells has generated much interest in the last two decades because these stem cells are linked to the aetiology of gastric cancer [23]. Understanding the behaviour of gastric cancer stem cells in different grades of cancer aids in devising ways of inhibiting them, which is of therapeutic value. Various proteins regulate gastric cancer stem cell properties. These include Bmi-1 [24] and Sox2 [22]. Detailed 
understanding of these regulatory proteins may result in significant contributions to acceptable prognosis of gastric cancer. It has been reported that the expression of CHEK2 is down-regulated with advancement in stages of prostate cancer [25].

In the present investigation, the expression profile of CHEK2 in the early and advanced stages of gastric cancer, and the expression of gastric cancer stem cell marker was analysed. Results from histology revealed that as the tumour progressed, the gastric tissue cells become complex in nature and invaded neighbouring tissues. CD44 is a cell surface gastric stem cell marker that plays a major role in adhesion and tissue invasion [22]. Recent studies related to CD44 found that the suppression of gastric cancer works by targeting CD44 through miR-145 [26].

In the current study, data from immunohistochemistry and western blotting revealed that at the initial stage of gastric tumour, the expression of CD44 was raised, but the increase in expression was comparatively more at the advanced stage of cancer. From the results, it can be inferred that the chemoresistance behaviour of gastric cancer occurs at the advanced stage of cancer due to increasing population of gastric cancer stem cells. The expression of CHEK2 followed a similar pattern as that of CD44 in normal and early stage of gastric cancer tissue, but the expression pattern of CHEK2 was down-regulated as the tumour developed to the advanced stage. By correlating the results with results from cancer studies, it can be inferred that in response to tumour development, the cell expresses more CHEK2 protein to control abnormal cell proliferation in early stage of gastric cancer, but in the advance stage of gastric cancer the expression of CHEK2 is down-regulated, resulting in loss of significant regulatory effects on gastric cancer stem cells.

\section{CONCLUSION}

The results of the current study suggest that the higher expression of CHEK2 at the early stages of gastric cancer exerts control over gastric stem cells. Thus, treatment at this stage would produce better outcomes than treatment at the advance stage of gastric cancer.

\section{DECLARATIONS}

\section{Acknowledgement}

Financial support for this study provided by Ren $\mathrm{Ji} \mathrm{Hospital} \mathrm{is} \mathrm{gratefully} \mathrm{acknowledged.}$

\section{Conflict of interest}

No conflict of interest is associated with this study.

\section{Contribution of Authors}

The authors declare that this work was done by the authors named in this article and all liabilities pertaining to claims relating to the content of this article will be borne by them. Lin-Hua Ji and Bin Zhang drafted this manuscript and performed all the experience under the supervision of Gang Zhao.

\section{REFERENCES}

1. Ferro A, Peleteiro B, Malvezzi M, Bosetti $C$, Bertuccio $P$, Levi $F$, Negri $E$, La Vecchia $C$, Lunet $N$. Worldwide trends in gastric cancer mortality (1980-2011), with predictions to 2015, and incidence by subtype. Eur $J$ Cancer 2014; 50: 1330-1344.

2. Jemal A, Bray F, Center MM, Ferlay J, Ward E, Forman D. Global cancer statistics. CA Cancer J Clin 2011; 61: 69-90.

3. Ruddon RW. Cancer biology. Oxford University Press; 2007.

4. Torre LA, Bray F, Siegel RL, Ferlay J, Lortet-Tieulent J, Jemal A. Global cancer statistics, 2012. CA Cancer J Clin 2015; 65: 87-108.

5. Lazăr DC, Tăban S, Cornianu M, Faur A, Goldiş A. New advances in targeted gastric cancer treatment. World $J$ Gastroenterol 2016; 22: 6776-6799.

6. Wroblewski LE, Peek Jr RM. H. pylori in gastric carcinogenesis-mechanisms. Gastroenterol Clin North Am 2013; 42: 285-298.

7. Akoh JA, Macintyre IMC. Improving survival in gastric cancer: Review of 5-year survival rates in English language publications from 1970. Br J Surg 1992; 79: 293-299.

8. Siegel R, Xu J, Thun MJ. Cancer statistics, 2009. CA Cancer J Clin 2009; 59: 225-249.

9. Siegel $R$, DeSantis C, Jemal A. Colorectal cancer statistics, 2014. CA Cancer J Clin 2014; 64: 104-117.

10. Clarke MF, Dick JE, Dirks PB, Eaves CJ, Jamieson CHM, Jones DL, Visvader J, Weissman IL, Wahl GM. Cancer stem cells-perspectives on current status and future directions: AACR Workshop on cancer stem cells. Cancer Res 2006; 66: 9339-9344.

11. Xu G, Shen J, Yang XO, Sasahara M, Su X. Cancer stem cells: the "heartbeat" of gastric cancer. J Gastroenterol 2013; 48: 781-797.

12. Schulenburg A, Blatt K, Cerny-Reiterer S, Sadovnik I, Herrmann H, Marian B, Grunt TW, Zielinski CC, Valent $P$. Cancer stem cells in basic science and in translational oncology: can we translate into clinical application? J Hematol Oncol 2015; 8: 16. 
13. Goel G, Sun W. Advances in the management of gastrointestinal cancers-an upcoming role of immune checkpoint blockade. J Hematol Oncol 2015; 8: 86.

14. Smith $A D$, Roda $D$, Yap TA. Strategies for modern biomarker and drug development in oncology. J Hematol Oncol 2014; 7: 70.

15. Network CGA. Comprehensive molecular characterization of human colon and rectal cancer. Nature 2012; 487: 330-337.

16. Pujana MA, Han J-DJ, Starita LM, Stevens KN, Tewari M, Ahn JS, Rennert G, Moreno V, Kirchhoff T, Gold B. Network modeling links breast cancer susceptibility and centrosome dysfunction. Nat Genet 2007; 39: 13381349.

17. Porkka KP, Visakorpi T. Molecular mechanisms of prostate cancer. Eur Urol 2004; 45: 683-691.

18. Knappskog S, Chrisanthar R, Løkkevik E, Anker G, Østenstad B, Lundgren S, Risberg T, Mjaaland I, Leirvaag $B$, Miletic $H$. Low expression levels of ATM may substitute for CHEK2/TP53 mutations predicting resistance towards anthracycline and mitomycin chemotherapy in breast cancer. Breast Cancer Res 2012; 14: R47.

19. Schmitt CA, Fridman JS, Yang M, Lee S, Baranov E, Hoffman RM, Lowe SW. A senescence program controlled by $p 53$ and p16 INK4a contributes to the outcome of cancer therapy. Cell 2002; 109: 335-346.
20. Japanese gastric cancer treatment guidelines 2010 (ver. 3). Gastric Cancer 2011; 14: 113-123.

21. Stoscheck CM. Quantitation of Protein. Methods in Enzymology 1990; 182: 50-69.

22. Zhang $X$, Hua R, Wang $X$, Huang M, Gan L, Wu Z, Zhang $J$, Wang $H$, Cheng $Y, L i$ J. Identification of stem-like cells and clinical significance of candidate stem cell markers in gastric cancer. Oncotarget 2016; 7: 98159831.

23. Wang $X$, Wang $C$, Zhang $X$, Hua $R$, Gan L, Huang $M$, Zhao L, Ni S, Guo W. Bmi-1 regulates stem cell-like properties of gastric cancer cells via modulating miRNAs. J Hematol Oncol 2016; 9: 90.

24. Takaishi S, Okumura T, Tu S, Wang SSW, Shibata W, Vigneshwaran R, Gordon SAK, Shimada Y, Wang TC. Identification of gastric cancer stem cells using the cell surface marker CD44. Stem Cells 2009; 27: 1006-1020.

25. Fan $X$, Chen X, Deng $W$, Zhong G, Cai Q, Lin T. Upregulated microRNA-143 in cancer stem cells differentiation promotes prostate cancer cells metastasis by modulating FNDC3B expression. BMC Cancer 2013; 13: 61 .

26. Zeng J-F, Ma X-Q, Wang L-P, Wang W. MicroRNA-145 exerts tumor-suppressive and chemo-resistance lowering effects by targeting CD44 in gastric cancer. World J Gastroenterol 2017; 23: 2337-2345. 